\title{
THE EUCHARIST AND THE MINISTERIAL PRIESTHOOD A REPLY TO KENNETH COLLINS AND JERRY WALLS
}

\author{
PATRICK LEE ${ }^{*}$
}

Franciscan University of Steubenville

\begin{abstract}
In chapters 9 and 10 of their book Roman but Not Catholic, Kenneth Collins and Jerry Walls criticize the Roman Catholic positions on the Eucharist as a sacrifice and on the ministerial priesthood. I reply to their historical and theological objections, and defend the belief that the Eucharistic sacrifice, the Mass, is a re-presentation, or making present, of Jesus's redemptive sacrifice on Calvary, and a key component in God's incarnational strategy for redeeming us.
\end{abstract}

KEY WORDS: Eucharist, redemption, re-present, sacrifice, Roman Catholic

\section{Introduction}

Kenneth Collins and Jerry Walls' Roman but Not Catholic continues a needed discussion on the differences between Catholic and Protestant beliefs and worship. They are sharply critical of the (Roman) Catholic position. This journal has invited me, a Catholic, to engage their work. Others have written reviews of their book as a whole, but here I will focus on one specific issue they address, the Eucharist or Lord's Supper. Collins and Walls (henceforth CW) helpfully preface their criticisms by reminding us of what we have in common: faith in God, Christ, Christ's saving death and Resurrection, and God's offer of grace and salvation. I do not want to deemphasize that commonality, but I will discuss here points of disagreement regarding the Eucharist and the priesthood (Chapters 9 and 10).

The Catholic belief is that the celebration of the Eucharist, or the Mass, is a re-presentation of the redemptive sacrifice of Christ on Calvary. Catholics are invited to participate in and unite their own lives to this sacrifice. CW argue that this belief is an accretion and distortion of the teaching of the Bible. They hold that the Eucharist is not a sacrifice but a fellowship meal, and that the Catholic doctrine and practice distorts the biblical doc-

* PATRICK LEE (PhD 1980, Marquette University) is Professor of Philosophy at the Franciscan University of Steubenville. Email: PLee@franciscan.edu. 
trine on how we are redeemed (CW: 145). They concede that the Lord's Supper has a sacrificial theme, but it is not a sacrifice, and there is no ministerial office of priests in the new covenant to offer sacrifice.

The Catholic Church teaches that Holy Orders is a sacrament that bestows a distinct capacity-in theology manuals and Church documents referred to as a 'character'-to offer, in behalf of the Church as a whole, the sacrifice of the Mass. The Church also teaches that there is a universal priesthood of all baptized Christians, which includes the capacity to offer the Mass through and with the ordained priestly minister.

CW advance three arguments against the Catholic doctrine and practice on the Eucharist and the priesthood. First an historical argument. They claim that neither the idea that any Christian ministers are priests, nor the idea that the Eucharist is a sacrifice, is anywhere to be found in the NT, and was not known before the late second century.

Second, they argue that the Catholic belief regarding the priesthood and the Eucharistic sacrifice illegitimately hearkens back to the Levitical priesthood of the Old Testament.

Third, they contend that these notions detract from our reverence for Christ's holy and perfect sacrifice. Christ's redemptive sacrifice redeems us and is sufficient. The addition of new sacrifices is useless and denigrates the one sacrifice of Christ (Hebrews 10: 11-14).

In the next section I briefly respond to the historical claims; and in subsequent sections I will discuss their theological objections and explain why I think the Catholic notions of the Mass and the priesthood are credible and cohere well with God's choice to redeem and sanctify through the Incarnate Word.

\section{The Historical Case}

CW express their historical claim with great vigor, but I think it is misleading. They say it is clear that in both the NT and the early Church the Last Supper is viewed as only a fellowship meal, albeit with sacrificial 'themes', and that nowhere is there a ministerial priesthood of the new covenant in the NT.

However, in the first place, as I explain below in the next section, the accounts of the Last Supper (in the synoptic gospels and St. Paul) indicate that Christ identifies what he does there as a sacrifice, and he tells the apostles to continue to do what he is doing-referred to as 'this' (tauto).

Second, St. Paul's account of the Eucharist seems to indicate that Paul and the early Christians believed that the Eucharist included consuming God's body and blood and that this was a way of communing with Christ as sacrificed. St. Paul writes: 
The cup of blessing that we bless, is it not a participation in the blood of Christ? The bread that we break, is it not a participation in the body of Christ? Because there is one bread, we who are many are one body, for we all partake of the one bread. Consider the people of Israel: are not those who eat the sacrifices participants in the altar? What do I imply then? That food offered to idols is anything, or that an idol is anything? No, I imply that what pagans sacrifice they offer to demons and not to God. I do not want you to be participants with demons. You cannot drink the cup of the Lord and the cup of demons. You cannot partake of the table of the Lord and the table of demons (1 Corinthians 10: 16-21).

St. Paul's reasoning is based on the parallel, on the one hand, between the Eucharist and the sacrifices in Israel, and, on the other, between those acts and the act of sacrificing to demons. The reasoning makes sense only if in each case there is a sacrifice. And in each case-he reasons-there is a consuming of the victim of a sacrifice and this is a way of communing, or attempting to commune, with the one to whom sacrifice is made (Miguens: 124).

Third, CW's assertion that the early Church conceives of the Lord's Supper as only a fellowship meal does not seem true. Although they advert to parts of the Didache and St. Justin Martyr, I believe that both writings are more naturally interpreted as attesting to a belief that the Eucharist is a sacrifice. The Didache is a very short set of instructions for converts. Still, what the Didache actually says about the Eucharist is suggestive:

On every Lord's Day-his special day-come together and break bread and give thanks, first confessing your sins so that your sacrifice may be pure. Anyone at variance with his neighbor must not join you, until they are reconciled, lest your sacrifice be defiled. For it was of this sacrifice that the Lord said, 'Always and everywhere offer me a pure sacrifice; for I am a great King, says the Lord, and my name is marveled at by the nations' (Didache 1953: 178; the quote from within is from Malachi 1:11, 14).

What is referred to by the word 'sacrifice' - the same sacrifice apparentlyin each of the three sentences? One might want to say that it refers only to the bread and wine, or other gifts perhaps, contributed by those coming to that celebration. However, it seems more natural to interpret it in line with St. Paul's letter, understanding the authors as aware that what is involved here is a profound mystery.

CW also refer to St. Justin the Martyr as showing (they say) that in the early Church the Lord's Supper was viewed as only a fellowship meal. Yet in the same work to which they refer (the First Apology) Justin writes:

This food we call Eucharist, of which no one is allowed to partake except one who believes that the things we teach are true, and has received the for for- 
giveness of sins and for rebirth, and who lives as Christ handed down to us. For we do not receive these things as common bread or common drink; but as Jesus Christ our Savior being incarnate by God's word took flesh and blood for our salvation, so also we have been taught that the food consecrated by the word of prayer which comes from him, from which our flesh and blood are nourished by transformation, is the flesh and blood of that incarnate Jesus. For the apostles in the memoirs composed by them, which are called Gospels, thus handed down what was commanded them: that Jesus, taking bread and having given thanks, said, 'Do this for my memorial, this is my body'; and likewise taking the cup and giving thanks he said, 'This is my blood'; and gave it to them alone (Justin 1953: 286).

Justin does not here explicitly say that the Eucharist is a sacrifice. However, he says it is the body and blood of Our Lord himself that is consumed, indicating that this is a sacred mystery, evidently more than (in his belief) a mere commemorative symbol. Moreover, given the Israelite background, he obviously is aware that the one whose body and blood is consumed is the one who has been offered, and that this consuming is the sealing of the covenant (more on this below).

Also, in his Dialogue with Trypho Justin does seem explicitly to identify the Eucharist as a sacrifice: 'Accordingly, God, anticipating all the sacrifices which we offer through this name, and which Jesus the Christ enjoined us to offer, i.e., in the Eucharist of the bread and the cup, and which are presented by Christians in all places throughout the world, bears witness that they are well-pleasing to Him' (Justin 1973: 257).

CW's sweeping assertion regarding the priesthood also is mistaken: 'With the notable exception of Christ himself (for example, in Hebrews 7), it is impossible to find in the pages of the NT a sacerdotal priesthood, marked with all sorts of powers and indelible marks, one that is distinguished from the rest of the church' (CW: 174-175).

While it is true that nowhere in the NT is the term 'priest'-the Greek hierus-applied to the apostles or their successors, nevertheless the terms episocopus or presbyter seem in some cases to refer to offices that include the office of making present Christ's priesthood in the Eucharist. There is some fluidity in these terms; in some cases, the terms seem to be used interchangeably. There is a natural explanation for why the term 'hierus' was avoided. First, to avoid confusion, since that term was still being used to refer to priests in the Jewish practice. Second, the ministerial priesthood of the apostles and their successors was a new type of office or functioninstead of directly offering a sacrifice for the community, their role (or this part of their role) is to perform the act that makes present Christ's sacrifice (I discuss this below). [Note also that in several places St. Paul describes his ministry as a priestly one (Romans 15: 15-16; Philippians 2:17; 2 Timothy 4:6) These texts could be interpreted in various ways, of course, but they 
indicate that Paul did not see his role only as a teacher but that it included in some way a priestly role. In 1 Corinthians 4:1 he says: 'This is how one should regard us, as servants of Christ and stewards of the mysteries of God'. These mysteries include more than doctrines; they also include deeds or actions.]

CW also claim that the early Church did not have the idea of an actual priesthood in the new covenant. While discussing Tertullian's description (third century) of a distinct role for priests, they claim: 'This last move, however, was a much later development. Indeed, there is no objective evidence that the first-century church, made up of Jesus and his disciples, affirmed the notion of a 'priest' within the church other than the general or common priesthood of all believers as reflected in Revelation 1:6; 5:10; 20:6; 1 Peter 2:5, 9, and the priesthood of Christ himself' (CW: 175).

Again, the historical record does not support this sweeping judgment. The first Letter of Clement (written around 95), seems to take for granted that the presbyters or episcopoi have a function or office different from the faithful in general, an office given to them through the imposition of hands (Clement 1953: 63-64). Around the year 95 Clement, a bishop of Rome, wrote to Corinth in order to settle a dispute between Christians there and presbyters against whom they had revolted. He reminds them that the apostles themselves had appointed episcopoi (overseers or bishops) and they in their turn had appointed men to succeed them in that office. For this reason, Clement insists, it would be no small sin to remove those now holding that office. He then says: 'In the light of this, we view it is a breach of justice to remove from their ministry those who were appointed either by them [i.e. the apostles] or later on and with the whole church's consent, by others of the proper standing, and who, long enjoying everybody's approval, have ministered to Christ's flock faultlessly, humbly, quietly, and unassumingly' (Clement 1953: 63-64). This suggests that the espiscopate or presbyterate was a fixed office, and that it included making offering of gifts or sacrifice, though the text does not identify what gifts (dona) are offered.

Near the same time, St. Ignatius of Antioch indicates quite explicitly the belief that the Eucharist is a sacrifice.

Let no one be misled: heavenly beings, the splendor of angels, and principalities, visible and invisible, if they fail to believe in Christ's blood, they too are doomed... Pay close attention to those who have wrong notions about the grace of Jesus Christ, which has come to us, and note how at variance they are with God's mind... They hold aloof from the Eucharist and from services of prayer, because they refuse to admit that the Eucharist is the flesh of our Savior Jesus Christ, which suffered for our sins and which, in his goodness, the Father raised (Ignatius 1953: 114). 
And further down Ignatius explains that the Eucharist must be celebrated only by the bishop (espiscopos) or someone authorized to do so by the bishop, mentioning also the presbyterate:

Flee from schism as the source of mischief. You should also follow the bishop as Jesus Christ did the Father. Follow, too, the presbytery as you would the apostles; and respect the deacons as you would God's law. Nobody must do anything that has to do with the Church without the bishop's approval. You should regard that Eucharist as valid which is celebrated either by the bishop or by someone he authorizes. Where the bishop is present, there let the congregation gather, just as where Jesus Christ is, there is the Catholic Church (Ignatius 1953: 115).

And to the congregation in Philadelphia he wrote:

Be careful, then, to observe a single Eucharist. For there is one flesh of Our Lord, Jesus Christ, and one cup of his blood that makes us one, and one altar, [The word translated as 'altar' is 'thusiasterion'. Literally, or at least etymologically, this is: place of sacrifice.] just as there is one bishop along with the presbytery and the deacons, my fellow slaves (Ignatius 1953: 108).

Thus, there seems to be good evidence that the apostles appointed certain men to carry on the ministry of being 'stewards of the mysteries of God' (1 Corinthians 4:1), and that this ministry included offering the Eucharistic sacrifice on behalf of the Church.

\section{Jesus's Sacrificial Redemptive Act}

CW claim that the Catholic doctrine and practice of the Mass is incoherent, that it rests on superseded ideas connected to the old covenant, Levitical priesthood, and that it detracts from Christ's fully sufficient sacrifice on the cross, and his perfect priesthood. In this section I explain why, on the contrary, the Mass is central to understanding the wisdom and splendor of God's strategy for redeeming and sanctifying us. And in the last section I will answer CW's objections regarding its coherence, and its relation to the Levitical priesthood and Christ's perfect and eternal priesthood.

After our sin and alienation from God, God freely chose to re-establish for us union with him. God could have re-united us to him in various ways. For example, he might have done so in a purely spiritual way without our cooperation and without any mediator. Instead, as Scripture and the teaching of the Church proclaim, the Incarnation and Christ's passion, death, and resurrection are the means by which sin-our alienation from God-is overcome and we are brought back into union with God. The God-man Jesus is the mediator, or the way in which, we are re-united with God. But how does Jesus's life, passion, death, and resurrection do that? How are we saved by Jesus's death on the cross and his resurrection? 
The NT (including Jesus himself) speaks of Christ's death on the cross as a ransom, and the effect of his death has also traditionally been called redemption, and a satisfaction for our sins. Also, Jesus is called the Lamb of God, and his death is described as a sacrifice given for our sins. How should these descriptions or comparisons be understood?

One understanding of how Christ's death redeems is the penal substitution theory. This view compares Christ's atoning act with a literal ransoming or redeeming. The idea is that our sins-both original sin and our personal sins-deserve punishment. But out of love and mercy God became man and paid that penalty for us, and thus the scales of justice have been set right, our debt has been paid, and we can now be re-unified with the Father.

This view of redemption cohered well with the reformers' notion of extrinsic, or imputed, justification. On this view justification-our being made just or straight with God-is not an internal transformation in us, but God's decision not to regard us as alienated from him, or regard us as deserving of punishment, in view of Christ's passion and death. So, Christ's passion and death literally constituted a payment, a price, that purchased our justification.

One problem with this notion of redemption is that it is not clear who is being paid. Some who held this view thought that the devil was the one paid - that Christ paid a ransom to the devil to free us. It is true that one of the effects of the atonement is the removal of a kind of subjection to the devil, but it is not coherent to think that God needed to pay the devil to make things right. Neither God nor Jesus in his human nature owed the devil anything, and the devil certainly did not gain anything by Jesus's death on the cross. Perhaps it is God who is paid? But

Jesus's death, just as such, does not provide God, who is infinitely perfect, a benefit.

Moreover, it seems to be in itself unjust to punish one person for the sins committed by someone else. It is true that as a result of Jesus's suffering and death we need not suffer the punishment we otherwise would have; but that is not because Jesus was punished in our stead. His suffering and death were in our stead but not payments made to anyone. Thus, the metaphor of a ransom is not exact. Christ's atoning passion and death is similar in some important ways to paying a ransom (or redeeming a slave), but not every element of a literal ransom has a counterpart in Jesus's atoning passion and death (Kereszty 1991: chapter 4).

Jesus's death is also a sacrifice. A sacrifice is an offering or gift to God, an external immolation or setting-aside of something that is valuable to the ones offering the sacrifice, as an expression of their internal devotion to God. At the Jewish Passover, a lamb was immolated and offered up to God. 
Jesus is called the Lamb of God (John 1: 29 \& 36); his death is similar to the lamb's at Passover.

But what is redemptive or salvific is not the death as such-which is a privation that does not of itself (directly) cause anything good. Moreover, if the death itself were what saves us, then the Roman soldiers would be our saviors rather than Jesus. Rather, it is Jesus's internal act, that results in his death, that saves us and constitutes the central sacrifice of himself to the Father. Moreover, Jesus did not directly choose his death; he was not a suicide. The structure of his action was rather like that of a martyr. He chose to continue his mission, which required confronting the governing Jewish authorities in Jerusalem, knowing that this would result in his being killed. Thus, like a martyr, his death was a side effect of what he directly intended or chose. He chose to go to Jerusalem and celebrate the Passover with his apostles, foreseeing and thus accepting as a side effect, that he would be killed.

St. Paul writes that Christ 'became obedient unto death, even death on a cross' (Philippians 2:8). It is this obedience unto death-which is actually the culmination of his whole living of his life for the Father, his dedication or commitment 'to do the will' of his father-that is Christ's offering of himself, and so constitutes a true sacrifice. So, what is salvific is Jesus's internal offering of himself to the Father, his obedience unto death.

But this offering for the sake of humankind is a human act by Jesus. And a human act, even the human act of Jesus who is both God and man, is not of itself enough to overcome the alienation between man and God. And so there is also the divine response to this offering. Jesus's decision to go to Jerusalem to confront the leaders of the Jewish people and to celebrate the Passover with his apostles is his offering of himself as man to the Father. The Father then accepts and approves of this offering by raising Jesus from the dead. This self-offering by Jesus (as man) and the divine response in the resurrection together constitute the perfecting of the union between God and Jesus as man, as leader of the new covenant. The union establishes a new covenant between God and humankind. This union is itself the new covenant by which God communicates to us his own divine life. And so it is by being joined to this union, and by participating or cooperating with this union, that we are brought back to the Father, that is, redeemed.

\section{Jesus' Redemptive Act Made Present in the Mass}

The old covenant between the Israelite people and God was sealed by the blood of a sacrificed animal; the victim's blood was then sprinkled on the altar, and a covenant meal was shared in the presence of God, symbolizing the union of the two parties of the covenant (Exodus 24: 3-11). Similarly, during the Last Supper Jesus teaches that his own blood is the sealing of a 
new covenant, and the union between God and us is built up by consuming the body and blood of Jesus. The Lord's Supper makes present the new covenant union. Here is Matthew's account of the Lord's Supper:

Now as they were eating, Jesus took bread, and after blessing it broke it and gave it to the disciples, and said, 'Take, eat; this is my body'. And he took a cup, and when he had given thanks he gave it to them, saying, 'Drink of it, all of you, for this is my blood of the covenant, which is poured out for many for the forgiveness of sins (Matthew 26: 26-29; also see: Mark 14:22-25; Luke 22:14-23; 1 Corinthians 11:23-26).

According to Luke's account Jesus takes the bread, blesses it, breaks it, and then says: 'This is my body, which is given for you', He then adds: 'Do this in remembrance of me' (Luke 22:19). Similarly, St. Paul in First Corinthians describes 'what I received from the Lord and deliver to you'. According to Paul, Jesus said, after taking the cup: 'This cup is the new covenant in my blood. Do this, as often as you drink it, in remembrance of me' (1 Corinthians 11:23 and 25).

Thus, these accounts indicate that Jesus intended the Last Supper as a sacrifice, or the external expression of his sacrifice; and they indicate that this sacrificial act is the beginning of the new covenant-that Jesus's act selfoffering is the act that forms the new covenant community, the Church (Grisez 1983: chapter 22).

The 'remembrance' that Jesus commands the apostles to do, is not merely a calling to mind. It is a performative act. When the Jews celebrated the Passover meal they did more than call to mind the covenant; they renewed it, in a real sense making it present or extending it in time. Jesus's sacrificial choice will be made present by the actions of the apostles and the priests they appoint to succeed them, for us to participate and cooperate with.

To understand this somewhat we must first note that a choice is not the same as the behavior one performs to carry out that choice. A choice to meet someone at a certain place is different from the actual behavior one performs to carry out that choice. Likewise, in a sacrifice, the internal act (choice) of devotion or self-gift to God is distinct from the outward expression of that in an immolation or setting-apart of something as an external gift to God (Grisez 1983: chapter 9).

Second, the choice a person makes is not a temporary process. The behavior may last only a very short time or somewhat longer, but when one chooses one directs one's will in this direction or the other, and that choice, that direction of one's will, is not transitory. That choice remains as part of one's will or oneself unless or until one reverses it. Thus, large choices such as commitments (large in the sense that they bear on forming a relationship with another person or persons) last and are typically carried out by many 
different performances spread out over many years. The commitment of marriage, for example, remains as part of oneself and is implemented by several smaller choices and outward behaviors (carryings out or executions of choices) throughout a lifetime.

A further point is that by sharing choices or commitments one really becomes one with the other person (or persons) with whom one shares that choice or commitment. Choices last as part of who one is, part of one's character, the central part of one's self. By our choices we form or constitute the kind of person that we are; one's character is constituted by one's choices. And so sharing a choice or a commitment with someone is becoming one, not just metaphorically, but literally, with that person.

These points help us to understand somewhat how Jesus's offering of himself at the Last Supper is renewed or made present again by the actions of the apostles and the priests they appoint to succeed them when they 'do this', as directed by Jesus. Jesus's sacrifice of himself is most centrally his internal offering of himself. And that internal offering begins with his choice to go to Jerusalem and celebrate the Passover meal with his disciples. This choice is his obedience unto death, the choice that includes his accepting his death as a side effect. When he tells the apostles to do this in remembrance of him, this indicates that his intention includes their performances that make present his choice, his obedience unto death, his sacrifice. He intends not only his performance at this Passover meal but all of the subsequent performances of the apostles and of the priests they appoint to succeed them.

The idea of a proxy for a marriage ceremony can partly illustrate what occurs (Grisez 1983: chapter 23.B, 33.B; also see: Kereszty 2004: 167-192; O'Connor 2005: 299-313). Suppose George and Hilda wish to marry, but George is overseas and cannot be visibly present. He asks John to be his proxy at the ceremony. At the ceremony, John says, 'I do', he is acting as a proxy for George. His 'I do', his behavioral performance, makes present George's marital consent and commitment. Similarly, when the ministerial priest says, 'This is my body', and 'This is my blood of the new covenant', that behavioral performance, in virtue of Christ's intention, makes present Christ's choice, his obedience unto death, his sacrifice.

Jesus's choice to be obedient unto death is still part of who he is; it is part of the resurrected Jesus. That choice is made present in the Mass. And so, like a proxy in a marriage ceremony, the human priest's performance at Mass-his consecration-really makes present Jesus's self-offering. This sacrifice of Jesus is the human part of the new covenant union between God, on the one hand, and Jesus as man and all of his followers, on the other. Thus, the covenant, the union re-established between God and humankind, 
is made present in the Mass so that we can, with God's grace working interiorly in our hearts, participate and cooperate with it, joining to it our lives.

Further, bodily persons become united by sharing commitments-for by doing so one constitutes oneself as one with the other-but also by carrying out those choices-implementing those choices together, in bodily ways that involve bodily cooperation. Thus, playing a game together, sharing a meal together, spouses having sexual intercourse-in such acts unity in commitment or choice is bodily expressed or embodied, and creates unity in bodily action. The mysterious bodily presence of Christ under the appearances of bread and wine in part serves to make the union of bodily persons with Jesus a union that is suited to real and full union between bodily persons. [Jesus, a divine person, is bodily in virtue of his human nature.]

The Mass, the re-presentation of Christ's redemptive act, extends Jesus's Incarnate presence through time and space. Thus, God continues to deal with us, to bring us back to him, in and through the Incarnate Lord Jesus. The Catholic understanding and teaching on this point is consistent with God's decision to become incarnate. [This point has been explained by various Catholic writers-for example, St. Augustine, St. Thomas Aquinas, and more recently Louis Bouyer, Charles Journet, Yves Congar, Karl Adam, and Germain Grisez.]

In my judgment, by following the Protestant belief on how we are united to Christ, CW have omitted a key component of God's strategy in redeeming and sanctifying us, his strategy for gathering all things together, in heaven and on earth, in Christ (Colossians 1:20). The choice to save us through the Incarnation is itself is a choice to enlist the active cooperation on the part of those redeemed or saved. The Catholic belief is that God's plan or strategy also includes enlisting our own active cooperation in handing on not only the words of Jesus describing his plan, but also his deedsthe saving actions themselves-so that we can participate in those actions, unite our wills to them, and integrate our whole lives with them. We have seen how this is the case, on the Catholic belief, with the Sacrifice of the Cross made present to us in the Mass.

\section{Theological Objections}

CW raise several theological objections to the Catholic doctrines on the Mass and the priesthood. Before looking at the two specific ones mentioned in the introduction I would like to note that both of them rest on a more basic or fundamental objection. At one point CW argue that the Catholic doctrine on the priesthood 'necessarily detracts from the exclusive divine role that only Christ as the God/Human can fulfill...' (CW: 195) However, this key argument assumes that divine causality and created causality are mutually exclusive-so that if you attribute an effect to one it can't also be 
attributed to the other. But cooperation, secondary causality-falsifies that assumption.

The general worry-shared by most of the Protestant tradition-is that Catholic doctrine attributes too much to creatures and specifically too much to human ministers or collaborators. Now it is absolutely true that the communication of divine life, grace, is an effect that is proportionate only to the divine nature; only God has the power to communicate a share in his divine life (2 Peter 1:4). But it does not follow that God cannot use human ministers, or human instruments as it were, by whom to produce such an effect. Bringing a created person into sharing in divine life is a divine work, but God can use a human minister by which to bring that about. An analogy: A meaningful and intelligible sentence can be produced only by an intelligent being; but that intelligent being can use an instrument, for example a piece of chalk, by which to produce an intelligible sentence on a chalkboard. The chalk really does cooperate to produce an intelligible sentence even though that effect is not proportionate to its nature or power. The chalk acts, not with its own power alone, but with the power or efficacy of the principal agent (the writer) in it, moving it to produce an effect greater than what is proportionate to its own power.

Likewise, anyone who believes in the Bible will grant that God has used human ministers as instruments or cooperators in his actions in the worldprophets, miracle-workers, speakers of tongues, etc. (1 Corinthians 12: 810). The miracles and the messages in such events are God's work-effects proportionate only to God's power-but in such cases human agents have cooperated with God. Catholics believe that ministerial priests operate similarly in the sacrifice of the Mass-acting as proxies, with his power working in them, to make present his self-offering and his body and blood. In addition, all of the Baptized Christians in attendance are able to participate in Jesus's self-offering that is made present, and join their particular offerings to Jesus's.

The central reason why divine and created causes are not mutually exclusive-including in the order of salvation-is that God causes the act of causing that the creature does perform; so, when both God and creature cooperate in producing an effect, the creature's cooperation itself is part of the gift God is giving. Moreover, there is reason to think that the more important the work or effect, the more likely it is that God will enlist secondary causes as cooperators. As Aquinas explained, in general the more perfect the cause, the more perfect the effect. But since God's power is so great, he makes creatures to be like him not only in being but also in acting. So, in general, Aquinas concluded, to deny the efficacy of creatures actually detracts from divine power rather than protecting or exalting it (Aquinas 1957: Bk. III, chapter 69). 
Of course, God does not need our cooperation; he could produce whatever effects he chooses without it. However, active cooperation in bringing about the plans of the creator is in itself valuable. Such active cooperation ennobles created agents. Think of a family where wise parents insist that the children help around the house. The parents might do this, not because they need the children's help, but because their children's active cooperation in keeping the house up and things running smoother is in itself valuable and is part of building family communion. A similar motive seems operative with God and the family he is building. God's plan is for all things to be united in Christ, things in heaven and things on earth (Colossians 1:20), the divine persons and the created persons who accept his invitation to be part of this community. But God's gift to us includes our works, our contributions-they are themselves gifts from God: 'For we are his workmanship, created in Christ Jesus for good works, which God prepared beforehand, that we should walk in them' (Ephesians 2:10). Our cooperation is part of God's gift, something that God works in us: 'For it is God who works in you, both to will and to work for his good pleasure' (2 Philippians 2:13). [It is not as if God and the human being each does a part in producing some effect, the way two people might cooperate to row a boat. Whenever God acts, the whole effect, not just part of it, is from God. Still, God's causality is such that human beings (or creatures in general) really do cooperate in bringing about certain effects.] Thus, divine and created causality are not mutually exclusive, not in fundamental competition, they do not make a zero-sum game.

CW object, more specifically, to the Catholic belief that human priests can be actual priests in the new covenant, that is, that a human person can make present Christ's sacrifice, for the sake of the Christian community. Quoting Franz Hildebrandt (who himself refers to Thomas Cranmer), they argue that because Christ is an eternal priest, 'the office which He holds 'passeth not away' into other hands... None of them ever 'take over' from Him' (CW: 192; from Hildebrandt 1967: 146). They argue that 'Rome's' claim that human priests act in persona Christi, in the person of Christ, 'necessarily detracts from the exclusive divine role that only Christ as the God/Human can fulfill...' (CW: 195).

However, the Catholic belief is not that the ordained human priests perform additional sacrifices. Christ is indeed the sole mediator, the unique and perfect high priest. The ministerial priesthood is not an additional mediation and does not perform additional sacrifices. Acting as a proxy for Christ, the ministerial priest makes present the one sacrifice of Christ. And his ministry of priesthood makes present the one, perfect, and eternal priesthood of Christ. 
God uses created agents to produce effects that are not proportionate to their natural powers but rather are proportionate to God's own power. Not all types of cooperation are the same, but there does not seem to be any reason to think that this is impossible in the order of salvation. The Catholic belief is that God has chosen to enlist the cooperation of human ministers and instruments for the communication of a sharing in his own divine life, an effect that obviously exceeds their natural power (Aquinas 1957: chapter $69)$.

One of the motifs Jesus returns to at several points, as recounted in the gospel of John, is the particular way in which Jesus is sent by the Father. Repeatedly Jesus says that he has been sent by the Father (John 3:13;6:38), but at the same time the Father is with him: 'He who sent me is with me. He has not left me alone...' (John 8:29). The Father has sent Jesus but the Father is present in him, so that what he and the Father do are one work. This point is the important background for the instances in which Jesus says to the apostles that he is sending them. He sends them, he says, as the Father has sent Him. In the prayer discourse he prays to the Father: 'As you sent me into the world, so I have sent them into the world' (John 17:18). And he tells the apostles that they are to bring reconciliation, the forgiveness of sins, to people. In doing so, he again adverts to the way the Father has sent him:

Jesus said to them again, 'Peace be with you. As the Father has sent me, even so I am sending you.' And when he had said this, he breathed on them and said to them, 'Receive the Holy Spirit. If you forgive the sins of any, they are forgiven them; if you withhold forgiveness from any, it is withheld' (John 20: 21-23).

Thus, Jesus is sending the apostles as the Father sent him, namely, not away, but in such a manner that he will continue to be with them. And so, they are to carry on his work, they are to do works requiring divine power. But Jesus will be in them, they and Jesus will be working together (cf. Matthew 28:20).

This point also helps to answer CW's objection that the Catholic priesthood models itself on the Levitical priesthood, with its repeated daily sacrifices (CW: 191-192). The Catholic Church appeals to the Levitical priesthood only as prefiguring the priesthood of Christ and the ministry of making Christ's sacrifice and priesthood present for our participation. And so the Church also insists that there are significant differences between the Levitical priesthood itself and what it prefigures. The sacrifice of Christ is not repeated or added to. Rather, the one sacrifice of Christ is made present but by many outward expressions or performances, themselves foreseen and intended by Christ in his one sacrificial choice.

CW consider the Catholic Catechism's assertion that the one priesthood of Christ, 'is made present through the ministerial priesthood without diminishing the uniqueness of Christ's priesthood' (Catholic Church 1997: 
\# 1545). CW reply that this is an empty claim, 'a claim that the ongoing positive good of the unique priestly role of Christ, which is at the very heart of the gospel, itself ever undermines'. They continue:

In short, this special, exclusive work of reconciling a God of holy love to a sinful humanity, given its very nature, requires nothing less than divinity, a trait that every Roman Catholic priest so obviously lacks. To be sure, divinity cannot be pretended or feigned or playacted without verging on either the blasphemous or the pathetic. Here there can be no fill-ins, no representatives, no substitutes (CW: 195-196).

However, this simply repeats the point that was argued against. The question was whether God could use human ministers (and others, including the person herself being justified or sanctified) as instruments in the communication of his divine life. The Catholic Catechism teaches that this is possible, that God has chosen to do so, and that this does not contradict the uniqueness of Christ's priesthood because it makes present, rather than substituting for, that unique priesthood. ${ }^{1}$ Merely to repeat that the effect is proportionate only to divinity adds nothing to circumvent or refute the argument.

There is, of course, at least one type of effect that God cannot share with instrumental or secondary causes, namely, creation from nothing-not because God's power is limited but because it would involve a selfcontradiction. An instrumental cause is operative only as shaping or giving

CW also advance two objections to the doctrine of transubstantiation. First, they claim that it logically implies that Jesus has two bodies. If the Catholic doctrine of transubstantiation is true, then, when Jesus at the Last Supper says, 'This is my body', it follows, they claim, that Jesus's body is in two places at once. It will have to be both sitting at the table and at the same time existing under the accidents of bread. Second, they argue it is unsuited to Christ's dignity that he be 'confined to a box'. Both criticisms, however, impose on the 'is' of 'This is my body' the meaning, spatially confined, with the result that bodies thus spatially confined cannot be in two places at one time and that being 'in' a tabernacle would require being limited or confined to it. The Catholic doctrine, however, does not assume or impose such a meaning on the notion of bodily presence. In the first place, the doctrine is not meant as explanation of the mystery; rather, it is heading-off denials of a genuine bodily presence. [Also, it does not, contrary to CW's claim, endorse the Aristotelian doctrine of accidents. The definition does not say that Christ is present under the accidents of bread and wine, but under the species (Latin for 'appearances'). What the doctrine says is that it is Christ, and it is not bread, even though it still looks like bread.] Once the assumption that bodily presence entails limitation to this or that space is set aside, neither criticism follows-there is no logical problem with the idea that a body could be present in two or more places at the same time. The logical problem is only with the idea that it can be present as confined to two or more places at one time. Likewise, if being present in place A does not preclude one's being present in other places, then there does not seem to be anything undignified about being present in a tabernacle. More, doing that seems consistent with God's general strategy for dealing with humankind. 
some particular determinacy to the action of the principal cause (as the chalk particularizes the way the writer writes). But because the contribution of the instrumental cause presupposes an effect to shape or particularize, there can be no instrumental cause in the act of creating from nothing (Aquinas 1947: Part I, Question 45, article 5). Thus, created entities can only impart a new structure or form to pre-existing subjects or materials, and so cannot create from nothing or cooperate in creation from nothing.

Now it is true that when what is brought about is the communication of divine life itself, instrumental causes (human beings, concrete signs such as words, water, chrism, and so on) cannot contribute to any intrinsic aspect of the effect, the divine indwelling, grace. But through Christ's arrangement, human beings and their actions can have an effect on the circumstances, for example, the when and where, of these divine actions. This is the manner, for example, in which the efficacy of a proxy works. The analogy of a proxy suggests how God as a principal personal agent might be present in a human being acting as a proxy for him (as the groom is present at his marriage ceremony through the actions of his proxy). These are only analogies and do not by themselves prove that what is proposed is possible, but they help to show that the claim that such actions are impossible has not been substantiated. In any case, there does not seem to be anything intrinsically impossible in God using a human instrument to make the sacrifice of Christ present on contemporary altars and of the Baptized Christians in attendance then being able to participate in that offering and join their prayers, works, joys and sufferings to it.

I have focused on the issues raised by CW's criticism of the Catholic doctrine and practice of the Mass and the priesthood. I have argued that their historical case omits important testimonies of the belief of the early Church. I also argued that the Catholic belief in the sacrifice of the Mass is a key component in God's strategy for redeeming and sanctifying us, a sign of credibility of the whole of Christian teaching. At the same time I appreciate the commonality in faith I share with Professors Collins and Walls and appreciate their frank discussion of these issues.

\section{Bibliography}

Aquinas T (1947) Summa Theologica, translated Dominican Fathers of the English Province. New York, NY: Benziger Brothers. Available online at: https://dhs-priory.org/thomas/summa/.

Aquinas T (1957) Summa Contra Gentiles, Book 3: Providence, translated Vernon J. Bourke. New York, NY: Hanover House. Available online at: https://dhsp-riory.org/thomas/english/ContraGentiles3a.htm. 
Catholic Church (1997) Catechism of the Catholic Church, Complete and Updated. New York, NY: Doubleday.

Clement of Rome (1953) The Letter of the Church of Rome to the Church of Corinth, commonly called Clement's First Letter, translated and edited by Cyril C. Richardson, in Library of Christian Classics, volume 1. Philadelphia, PA: Westminster Press.

Collins K and Walls J (2017) Roman but Not Catholic, What Remains at Stake 500 Years after the Reformation. Grand Rapids, MI: Baker Academic.

Didache, or The Teaching of the Twelve Apostles (1953) translated and edited by Cyril C. Richardson. In Library of Christian Classics, volume 1. Philadelphia, PA: Westminster Press.

Grisez G (1983) The Way of the Lord Jesus, volume 1: Christian Moral Principles. Chicago, IL: Franciscan Herald Press.

Ignatius of Antioch (1953) Letters of Ignatius, Bishop of Antioch, translated and edited by Cyril C. Richardson. In Library of Christian Classics, volume 1. Philadelphia, PA: Westminster Press.

Justin the Martyr (1953) The First Apology of Justin, the Martyr, translated and edited by Cyril C. Richardson. In Library of Christian Classics, volume 1. Philadelphia, PA: Westminster Press.

Justin the Martyr (1973) Dialogue with Trypho, translated and edited by Alexander Roberts and James Donaldson. In The Ante-Nicene Fathers, Translations of The Writings of the Fathers Downs to A.D. 325. Grand Rapids, MI: 1973)

Kereszty OCist R (1991) Jesus Christ, Fundamentals of Christology. New York, NY: Alba House.

Kereszty OCist R (2004) Wedding Feast of the Lamb, Eucharistic Theology from a Historical, Biblical, and Systematic Perspective. Chicago, IL: Hillenbrand.

Miguens OFM M (1976) Church Ministries in New Testament Times. Arlington, VA: Christian Culture Press.

O’Connor J (2005) Hidden Manna: a Theology of the Eucharist. San Francisco, CA: Ignatius Press. 